\title{
Assessment of Cardiovascular Risks due to Methylphenidate in Six Months of Treatment in Children with Attention Deficit and Hyperactivity Disorder
}

\author{
Mehmet Emre Ari', Ibrahim Ilker Cetin', Filiz Ekici', Abdullah Kocabas' ${ }^{1}$ Sancar Eminoglu', \\ Esra Guney ${ }^{2}$, Onder Ozturk², Gulser Senses Dinc², Zeynep Goker ${ }^{2}$
}

ÖZET:

Dikkat eksikliği hiperaktivite bozukluğu olan çocuklarda metilfenidat tedavisinin altıncı ayında kardiyovasküler risklerin değerlendirilmesi

Amaç: Dikkat eksikliği ve hiperaktivite bozukluğu (DEHB) nedeniyle metilfenidat kullanan hastalarda nadiren kardiyovasküler yan etkiler görülebilmektedir. Bu çalışmada, DEHB'li hastalarda metilfenidatın kardiovasküler sistem üzerine etkilerininin araştııılması planlandı.

Yöntem: Mayıs 2011-Mayıs 2012 tarihleri arasında DEHB tanısı ile metilfenidat tedavisi başlanan 141 hasta incelendi. Hastaların hepsi metilfenidat tedavisinden önce kardiyolojik açıdan değerlendirildi. Sonrasında hastalar metilfenidat kullandıkları süre boyunca üç ay aralar ile kardiyovasküler ve elektrokardiyografik (EKG) değişikliklerin değerlendirilmesi için kontrole çağrıldılar. Tedavinin başında ve ilk altı ayında hastaların tüm verileri değerlendirildi. Otuz beş (\%24.8) hastada ilk 6 ay içerisinde çeşitli kardiyovasküler yakınmalar görüldü. Demografik özellikler, kalp hızı, sistolik ve diyastolik kan basıncl, EKG ile QTc süresi, ritim Holter ve 24 saat kan basıncı monitorizasyonu sonuçları değerlendirildi.

Bulgular: Otuz beş hastanın (10'u kız ve 25'i erkek) ilk 6 ay içerisinde kardiyovasküler semptomu vardı. Hastaların yaş ortalaması $9.2 \pm 2.8$ yaş idi. Metilfenidat tedavisi sonrası QTc süresindeki artış istatistiksel olarak anlamlı bulunmakla birlikte $(p<0.05)$ bu artış normal sınırlardaydı. Benzer sekilde hastaların sistolik ve diyastolik kan basınçlarında da istatistiksel olarak anlamlı artı̧̧ bulundu. Bu artış sadece 5 hastada 90-95 persentil arasında idi. Bu hastaların tansiyon Holter sonuçları normal olduğu için metilfenidat tedavileri sonlandırımadı. Hastaların ortalama kalp hızlarında da artış vardı, ancak bu artış istatistiksel olarak anlamlı değildi. Kardiyovasküler semptomlar 16 hastada (\%45.8) çarpıntı, 11 hastada (\%31.5) göğüs ağrısı, 5 hastada (\%14.2) çarpıntı ve göğüs ağrısı ve 3 hastada (\%8.5) nefes darlığı idi. Bu hastaların tümünde EKG ve 24 saatlik ritim Holter sonuçları normal saptandı. İki hastanın tetkik sonuçları normal olmasına rağmen ailelerinin isteği ile tedavileri sonlandırıldı. Sonuç: DEHB hastalarında 6 aylık metilfenidat kullanımı sırasında QTc süresindeki uzama ile sistolik ve diyastolik kan basınçlarındaki artış istatistiksel olarak anlamlı bulundu. Bununla birlikte bu değişiklikler normal sınırlar içerisinde kaldı. Metilfenidat kullanan tüm hastalar kardiyovasküler yan etkiler açısından dikkatle izlenmelidir.

Anahtar sözcükler: dikkat eksikliği hiperaktivite bozukluğu, metilfenidat, kardiyovasküler riskler

Klinik Psikofarmakoloji Bulteni 2014;24(3):248-52

\section{ABSTRACT:}

Assessment of cardiovascular risks due to methylphenidate in six months of treatment in children with attention deficit and hyperactivity disorder

Objectives: Cardiovascular adverse effects can be seen rarely in patients receiving methylphenidate for attention deficit and hyperactivity disorder (ADHD). In this study, we planned to investigate the effects of methylphenidate on the cardiovascular system in ADHD patients.

Methods: One hundred and forty-one patients, who were diagnosed with ADHD and started on methylphenidate treatment between May 2011 and May 2012, were investigated. A cardiologic evaluation was performed on all of the patients before the methylphenidate treatment was begun. Subsequently, the patients were invited for regular visits at three months intervals for assessment of cardiovascular and electrocardiographic (ECG) changes during this treatment. The data of all these patients at the beginning of treatment and within the first 6 months were evaluated. Thirty-five patients $(24.8 \%)$ suffered from various cardiovascular symptoms in the first 6 months. Demographic characteristics, heart rate, systolic and diastolic blood pressures, QTC duration on ECG, rhythm Holter and 24-hour blood pressure monitoring results of these patients were evaluated.

Results: Thirty-five patients (10 girls and 25 boys) had cardiovascular symptoms in the first 6 months. The mean age of patients was $9.2 \pm 2.8$ years. Although QTC duration significantly increased after methylphenidate treatment $(p<0.05)$, this increase was within normal ranges. Similarly, systolic and diastolic blood pressures of patients increased significantly. This increase was between the $90-95^{\text {th }}$ percentiles in only 5 patients. Twenty-fourhour blood pressure monitoring results were normal, and the methylphenidate treatment of these patients was not stopped. The mean heart rate of patients was also increased, but this increase was not statistically significant. The symptoms with respect to the cardiovascular system were palpitations in 16 patients (45.8\%), chest pain in 11 patients (31.5\%), palpitations with chest pain in 5 patients (14.2\%) and dyspnea in 3 patients (8.5\%). All patients' ECG and rhythm Holter results were within normal limits. Two patients discontinued treatment because of their parent's unwillingness for the drug to be continued.

Conclusions: In ADHD patients, the elongation of QTC duration and increase in the systolic and diastolic blood pressures were statistically significant during 6 months of methylphenidate treatment. However, all these changes remained within normal limits. All patients receiving this drug should be monitored carefully for cardiovascular side effects.

Keywords: attention deficit and hyperactivity disorder, methylphenidate, cardiovascular risks

Bulletin of Clinical Psychopharmacology 2014;24(3):248-52
'Departments of Pediatric Cardiology, Ankara Child Health, Hematology Oncology, Education and Research Hospital, Ankara - Turkey

2Departments of Child and Adolescent Psychiatry, Ankara Child Health, Hematology Oncology, Education and Research Hospital, Ankara - Turkey

\section{Corresponding author:}

Mehmet Emre Ari,

Departments of Pediatric Cardiology, Ankara Child Health, Hematology Oncology, Education and Research Hospital, Ankara - Turkey

\section{E-mail address:}

memreari@yahoo.com

Date of submission:

February 24, 2014

Date of acceptance: July 2, 2014

Declaration of interest: M.E.Ari., I.I.C., F.E., A.K., S.E., E.G., O.O G.S.D., Z.G.: The authors reported no conflict of interest related to this article. 


\section{INTRODUCTION}

Attention deficit and hyperactivity disorder (ADHD) is one of the most common psychiatric disorders in children, effecting social and cognitive development and causing other psychiatric disorders during childhood and adolescence ${ }^{1}$. Five to seven percent of school-aged children suffer from this disorder. ADHD is 3-5 times more common in males than females ${ }^{2,3}$. Methylphenidate is an important psychostimulant drug that is commonly used for ADHD. It has been reported that the sympathomimetic (noradrenergic and dopaminergic) effects of methylphenidate might cause an increase in systolic and diastolic blood pressures and heart rate, QTc prolongation and arrhythmias and even sudden death in some patients ${ }^{4-8}$.

\section{PATIENTS AND METHODS}

The medical records of 141 patients admitted to the Child and Adolescent Psychiatry Department between May 2011 and May 2012 were reviewed. A detailed cardiologic evaluation was performed on all of the patients treated with methylphenidate before the treatment was begun. Subsequently, all of the patients were re-evaluated for cardiovascular and ECG changes at three month intervals during this treatment regimen. The physical examinations and ECG findings of all patients were normal at these visits. The patients describing clinical symptoms, which might be related to methylphenidate treatment, were enrolled in the study. Methylphenidate was given to all patients at an initial dose of $0.7-1 \mathrm{mg} / \mathrm{kg} /$ day. Thirty-five of these 141 children were referred to the Pediatric Cardiology department due to cardiovascular symptoms in the first 6 months of treatment. The findings before methylphenidate treatment and at presentation were reviewed. The demographic variables, heart rate, systolic and diastolic blood pressures, QTc interval calculated by Bazett's formula, 24-hour rhythm Holter and blood pressure Holter recordings and echocardiography results were analyzed and compared with the results obtained before the initiation of methylphenidate treatment. The study protocol was approved by the Hospital's Ethics Committee and informed consent was obtained from parents.

\section{Statistical Analysis}

The statistical analysis was performed by using the SPSS (Statistical Package for the Social Sciences, version 16.0). The patient distribution was normal, so the Paired Samples T test was used for comparison of mean values pre- and posttreatment. $\mathrm{P}$ values $<0.05$ were considered to be statistically significant.

\section{RESULTS}

In the first 6 months of the treatment, 35 (24.8\%) of 141 patients presented with symptoms of palpitations $(45.8 \%)$, chest pain $(31.5 \%)$ or dyspnea $(8.5 \%)$ (Table 1$)$. The mean age of the patients with cardiovascular complaints while receiving methylphenidate treatment was $9.2 \pm 2.8$ years and 25 of these patients $(71.4 \%)$ were male.

Table 1: Cardiovascular symptoms in the first six months of methylphenidate treatment

\begin{tabular}{lcc} 
& n & \% \\
\hline Palpitations & 16 & 45.8 \\
Chest pain & 11 & 31.5 \\
Palpitations + Chest pain & 5 & 14.2 \\
Dyspnea & 3 & 8.5 \\
Total & 35 & 100
\end{tabular}

The pre- and post-treatment mean QTc intervals were $373.7 \pm 21.7 \mathrm{~ms}$ and $385.9 \pm 33 \mathrm{~ms}$, respectively. This increase in post-treatment QTc interval was found to be statistically significant

\begin{tabular}{|c|c|c|}
\hline & $\begin{array}{c}\text { Before } \\
\text { Treatment }\end{array}$ & $\begin{array}{c}\text { After } \\
\text { Treatment }\end{array}$ \\
\hline Number of patients (n) & 35 & 35 \\
\hline Mean QTc interval (ms) & $373.7 \pm 21.7$ & $385.9 \pm 33$ \\
\hline Mean SBP $(\mathrm{mmHg})$ & $93.7 \pm 13.6$ & $99.2 \pm 12.2$ \\
\hline Mean DBP $(\mathrm{mmHg})$ & $59.8 \pm 10.2$ & $63.5 \pm 8.3$ \\
\hline Mean HR (beats/min) & $86.5 \pm 13.4$ & $87.5 \pm 15.7$ \\
\hline
\end{tabular}

SBP: Systolic blood pressure, DBP: Diastolic blood pressure, HR: Heart rate 
Table 3: Echocardiographic findings of patients

\begin{tabular}{lcc} 
& n & \% \\
\hline PFO & 2 & 5.7 \\
Secundum ASD & 1 & 2.9 \\
Secundum ASD + VSD & 1 & 2.9 \\
Mitral cleft + Mitral regurgitation & 1 & 2.9 \\
MVP + Mitral regurgitation & 2 & 5.7 \\
BAV + Aortic regurgitation & 3 & 8.6 \\
NORMAL & 25 & 71.3 \\
TOTAL & 35 & 100
\end{tabular}

PFO: Patent Foramen Ovale, ASD: Atrial Septal Defects, VSD: Ventricular Septal Defect, BAV: Bicuspid Aortic Valve MVP: Mitral Valve Prolapse

$(p<0.05)$. However, none of the patients had a pathologically long QTc interval while they had cardiovascular symptoms (Table 2).

The pre-treatment echocardiographic investigations revealed no pathological signs in 25 $(71.3 \%)$ of the patients, whereas $10(28.7 \%)$ of the patients had various congenital heart defects. The distribution of these congenital defects is presented in Table 3.

The pre- and post-treatment mean systolic blood pressures were $93.7 \pm 13.6 \mathrm{mmHg}$ and $99.2 \pm 12.2 \mathrm{mmHg}$, respectively. There was a statistically significant increase in systolic blood pressures of patients $(\mathrm{p}<0.05)$. Although 22 of 35 patients' systolic blood pressures increased after treatment, only five patients had elevated systolic blood pressure values between the $90-95^{\text {th }}$ percentiles. The increases in the remaining 17 patients were within normal ranges.

The pre- and post-treatment mean diastolic blood pressures were $59.8 \pm 10.2 \mathrm{mmHg}$ and $63.5 \pm 8.3$ $\mathrm{mmHg}$, respectively. There was a statistically significant increase in diastolic blood pressures of patients $(\mathrm{p}<0.05)$. Elevated diastolic blood pressures were found in 19 patients. Five patients had increases in diastolic blood pressure within the 90-95 ${ }^{\text {th }}$ percentiles. Increases in diastolic blood pressure of the remaining 14 patients were below the $50^{\text {th }}$ percentile and clinically not significant. Patients, who had elevated systolic and/or diastolic blood pressures within the $90-95^{\text {th }}$ percentiles, underwent 24-hour ambulatory blood pressure monitoring, which revealed readings within normal ranges for all patients. Therefore, they were continued on their methylphenidate treatment.

The pre- and post-treatment mean heart rates were $86.5 \pm 13.4$ and $87.5 \pm 15.7$ beats $/ \mathrm{min}$, respectively. These values showed no statistical significance ( $p>0.05)$. In Table 2 the pre- and posttreatment mean systolic and diastolic blood pressures and heart rate values are summarized.

Although these 35 patients were maintained on their current methylphenidate treatment, two patients' complaints continued and their methylphenidate treatment was stopped during follow-up.

\section{DISCUSSION}

ADHD is one of the most prevalent psychiatric disorders of childhood. The prevalence of ADHD in the school-age population is reported to be $5-7 \%$. It is seen 3-5 times more in males than in females. Seventy five percent of all ADHD diagnosed children worldwide receive various drug therapies. The mean duration of treatment is 2.5 years $^{9}$. In this study, ADHD was also found to be more common in males than females (approximately 2.5 times). Methylphenidate is one of the most preferred drugs in ADHD. However, because of some side effects attributed to this drug, caution is required.

It has been reported that methylphenidate may cause increases in blood pressure, serious cardiac arrhythmias and even sudden death. Because of its serious side effects and possible sudden death, the FDA issued a black box warning for methylphenidate in 2006. To minimize these side effects, a thorough cardiovascular examination should be performed and a detailed family history for cardiovascular events, including any history of sudden death, should be obtained ${ }^{10}$.

In this study, none of the patients' relatives had any history of serious cardiovascular diseases. The results of all system examinations were found to be non-significant. ECGs for all patients were obtained before the methylphenidate treatment was begun. No patients had any rhythm problems or QTc prolongation. Also, all patients were investigated by echocardiography before 
treatment and various structural heart diseases were detected in 10 of 35 patients $(28.7 \%)$. However, none of these cardiac defects was severe enough to create clinical signs and all the patients with cardiac defects were symptom-free before the treatment was initiated. Therefore, it was not possible to explain the subsequent symptoms with the existing cardiac defects. It has been shown that treatment with methylphenidate resulted in an increase of 3.8-8 $\mathrm{mmHg}$ in systolic and 1.5-14 $\mathrm{mmHg}$ in diastolic blood pressure ${ }^{11}$. It was hypothesized that this was due to the noradrenergic effects of methylphenidate. However, in some studies, methylphenidate treatment caused no changes in blood pressure ${ }^{12,13}$. Recently, in a study with a large sample size, conducted by Winterstien et al., systolic and diastolic blood pressure values were found to be raised by $2-7 \mathrm{mmHg}^{14}$. In our study, similar results were obtained. The results of the present study showed that mean systolic blood pressure was raised by $3.1 \mathrm{mmHg}$ in males, and $11.5 \mathrm{mmHg}$ in females; whereas the increase in mean diastolic blood pressure was $2.1 \mathrm{mmHg}$ in males and 7.5 $\mathrm{mmHg}$ in females. Although these increases were statistically significant, they were not found to be in the pathological ranges.

In the study by Winterstein et al. methylphenidate was found to cause an approximately 5 beats/min increase in heart rate ${ }^{14}$. Similarly, in the study by Safer et al. in the short term, the increase in the mean heart rate was found to be 11 beats $/ \mathrm{min}$. In the long term, this increase was found to be limited to 4 beats $/ \mathrm{min}^{15}$. However, in the study by Reiner et al., where children suffering from ADHD were compared to healthy controls, high pre-treatment mean heart rate was found to be decreased to the level of healthy controls after treatment ${ }^{16}$. In a study by Vitiello et al., it was shown that treatment with psychostimulants did not raise the risk for hypertension. It was also shown that tachycardia occurred only in the long term when there was an increase due to the cumulative dose ${ }^{17}$. In the present study, a 1 beat $/$ min increase in the mean heart rate was found and this increase was not statistically significant. The long-term effects of methylphenidate are planned to be investigated.

The combined administration of methylphenidate, amphetamine and other psychostimulant drugs increases the frequency of cardiac symptoms. A retrospective cohort study reported by Winterstein et al. with 50,000 ADHD pediatric patients has reported that admission to the emergency department because of cardiac symptoms was $20 \%$ higher in children using combined psychostimulant drugs than in the normal population ${ }^{14}$. In our study, 6 of 35 patients with cardiac symptoms were taking another psychostimulant drug with methylphenidate (risperidone in one patient, fluoxetine in two patients, and sertraline in one patient).

It is known that the QTc interval is an indicator of ventricular depolarization and repolarization and prolongation in the QTc interval is a risk factor for ventricular arrhythmias. According to a previous report, the QTc interval was not changed with psychostimulant drugs like risperidone and clotiapine $^{18}$. Similarly, recent reports investigating the effects of methylphenidate on the QTc interval showed a mild increase in heart rate and blood pressure, but no effect on the QTc interval ${ }^{19-21}$. In our study, there was a mean increase of $12.2 \mathrm{~ms}$ in the QTc interval and none of the individual results was in the pathological range.

In conclusion, we have clearly shown the effects of methylphenidate on the cardiovascular system in our study cohort. Although the increases in the blood pressure and QTc duration after initiation of the methylphenidate treatment remained within normal ranges, we think that these parameters should be monitored for the possibility of reaching significant levels causing life threatening cardiac adverse events. In addition, there is a need for further studies on this topic with larger patient cohorts. 


\section{References:}

1. Tannock R. Attention deficit hyperactivity disorder: advances in cognitive, neurobiological, and genetic research. J Child Psychol Psychiatry 1998;39(1):65-99. [CrossRef]

2. Schweitzer JB, Faber TL, Grafton ST, Tune LE, Hoffman JM, Kilts CD. Alterations in the functional anatomy of working memory in adult attention deficit hyperactivity disorder. Am J Psychiatry 2000;157(2):278-80. [CrossRef]

3. Weiss G. Attention deficit hyperactivity disorders. In Lewis M (editor). Child and Adolescent Psychiatry: A Compherensive Textbook. New York: Lippincott Williams and Wilkins;1991 p.554-61.

4. Nissen SE. ADHD Drugs and Cardiovascular Risk. N Engl J Med 2006;354(14):1445-8. [CrossRef]

5. Rapport MD, Moffitt C. Attention deficit/hyperactivity disorder and methylphenidate. A review of height/weight, cardiovascular, and somatic complaint side effects. Clin Psychol Rev 2002;22(8):1107-31. [CrossRef]

6. Volkow ND, Wang GJ, Fowler JS, Molina PE, Logan J, Gatley SJ, et al. Cardiovascular effects of methylphenidate in humans are associated with increases of dopamine in brain and of epinephrine in plasma. Psychopharmacology 2003;166(3):264-70.

7. Lucas PB, Gardner DL, Wolkowitz OM, Tucker EE, Cowdry RD. Methylphenidate-induced cardiac arrhythmias. N Engl J Med 1986;315(23):1485. [CrossRef]

8. Shimizu W. Effects of sympathetic stimulation on various repolarization indices in the congenital long QT syndrome. Ann Noninvasive Electrocardiol 2002;7(4):332-42. [CrossRef]

9. Weis M, Weis G. Attention deficit hyperactivity disorder. In Lewis $\mathrm{M}$ (editor). Child and Adolescent Psychiatry. Philadelphia: Lippincott Williams and Wilkins; 2002 p.64570 .

10. Buchhorn R, Conzelmann A, Willaschek C, Störk D, Taurines $\mathrm{R}$, Renner TJ. Heart rate variability and methylphenidate in children with ADHD. Atten Defic Hyperact Disord 2012;4(2):85-91. [CrossRef]

11. Joyce P, Nicholls M, Donald R. Methylphenidate increases heart rate, blood pressure, and plasma epinephrine in normal subjects. Life Sci 1984;34(18):1707-11. [CrossRef]
12. Findling R, Short E, Manos M. Short term cardiovascular effects of methylphenidate and adderall. J Am Acad Child Adolesc Psychiatry 2001;40(5):525-9. [CrossRef]

13. Bhat V, Grizenko N, Sanche S, Joober R. No relation between therapeutic response to methylphenidate and its cardiovascular side effects in children with attention-deficit/ hyperactivity disorder. Clin Med Insights Pediatr 2008;1:3742.

14. Winterstein AG, Gerhard T, Shuster J, Saidi A. Cardiac safety of methylphenidate versus amphetamine salts in the treatment of ADHD. Pediatrics 2009;124(1):75-80. [CrossRef]

15. Safer DJ. Relative cardiovascular safety of psychostimulants used to treat attention-deficit hyperactivity disorder. J Child Adolesc Psychopharmacol 1992;2(4):279-90. [CrossRef]

16. Buchhorn R, Müler C, Willaschek C, Norozi K. How to Predict the Impact of Methylphenidate on Cardiovascular Risk in Children with Attention Deficit Disorder: Methylphenidate Improves Autonomic Dysfunction in Children with ADHD. ISRN Pharmacol ;2012:170935. doi: 10.5402/2012/170935. [CrossRef]

17. Vitello B, Elliott GR, Swanson JM, Arnold LE, Hechtman L, Abikoff $\mathrm{H}$, et al. Blood pressure and heart rate over 10 years in the multimodal treatment study of children with ADHD. Am J Psychiatry 2012:169(2);167-77.

18. Nahshoni E, Spitzer S, Berant M, Shoval G, Zalsman G, Weizman A. QT interval and dispersion in very young children treated with antipsychotic drugs: a retrospective chart review. J Child Adolesc Psychopharmacol 2007:17(2);187-94. [CrossRef]

19. Stiefel G, Besag F. Cardiovascular Effects of Methylphenidate, Amphetamines and Atomoxetine in the Treatment of Attention-Deficit Hyperactivity Disorder. Drug Saf 2010:33(10);821-42. [CrossRef]

20. Hill SL, El-Khayat RH, Sandilands EA, Thomas SH. Electrocardiographic effects of methylphenidate overdose. Clin Toxicol (Phila) 2010:48(4);342-6. [CrossRef]

21. Wakamatsu A, Nomura S, Tate Y, Shimizu S, Harada Y. Effects of methylphenidate hydrochloride on the cardiovascular system in vivo and in vitro: a safety pharmacology study. J Pharmacol Toxicol Methods 2009:59(3);128-34. [CrossRef] 